\title{
RANCANG BANGUN SISTEM IDENTIFIKASI PENYAKIT ICE-ICE PADA CITRA CITRA RUMPUTLAUT DENGAN JARINGAN SYARAF TIRUAN BACKPROPAGATION
}

Ani Kurniawati ${ }^{1}$,Dedy Harto ${ }^{2}$

1e-mail.anniwatti2016@gmail.com

${ }^{2} e-m a i l$. dedyaborneo.ac.id

\begin{abstract}
This research aims to develop an identification system for ice-ice in seaweed images using the backpropagation neural network method with the output of healthy seaweed and diseased seaweed. This research was conducted at Amal beach, Tarakan Timur sub-district, Tarakan City. The method used in this research is to use image processing as image enhancement and initial processing of seaweed image data, both sick and healthy and identified using back propagation neural networks. Ice-ice disease in seaweed has characteristics that initially appear red spots on some of the thallus then turn pale yellow and finally gradually turn white. Another feature that is the impact of ice-ice disease can cause the thallus to become brittle and break easily. Based on these characteristics, the bitnik color or white spot is used as the basis for identifying ice-ice in seaweed. From the results of the identification system design using ANN BP which has been tested on the image data of healthy seaweed and the image of seaweed infected with ice-ice as much as 60 data, it produces an accuracy rate of $95 \%$. The $5 \%$ system inaccuracy is influenced by poor image data when taking images using an HP camera
\end{abstract}

Keywords-Ice-ice disease, Image processing, Backpropagation Artificial Neural Network (ANN)

Intisari-Penelitilitian ini bertujuan untuk membuat sistem identifikasi penyakit ice-ice pada citra rumput laut menggunakan metode jaringan syaraf tiruan backpropagasi dengan keluaran rumput laut sehat dan rumput laut sakit. Penelitian ini dilakukan dipantai Amal kecamatan Tarakan Timur Kota Tarakan. Meode yang digunakan dalam peneliatian ini adalah menggunakan pengolahan citra sebagai perbaikan citra dan melakukan pemrosesaan awal data citra rumput laut baik yang sakit maupun yang sehat dan diidentifikasi menggunakan jaringan syaraf tiruan backpropagasi. Penyakit ice-ice pada rumput laut mempunyai ciri-ciri yang awal timbulnya bintik-bintik merah pada sebagian thallus kemudian berubah menjadi kuning pucat dan akhirnya berangsur-angsur menjadi putih. Ciri lain yang dampak dari penyakit ice-ice dapat menyebabkan thallus menjadi rapuh dan mudah putus. Berdasarkan ciri-ciri tersebut, maka warna bitnik atau bercak putih digunakan sebagai dasar untuk mengidentifikasi penyakit ice-ice pada rumput laut. Dari hasil rancang bangun sistem identifikasi menggunakan Jaringan syaraf tiruan (JST) Backpropagation (BP) yang telah dilakukan pengujian terhadap data citra rumput laut sehat dan citra rumput laut yang terinfeksi penyakit ice-ice sebanyak 60 data maka menghasilkan tingkat akurasi $95 \%$. Ketidak akuratan system 5\% dipengaruhi oleh data citra yang kurang baik dalam pengambilan citra menggunkan kamera HP.
Kata kunci-Penyakit ice-ice, Pengolahan Citra, Jaringan Saraf Tiruan (JST) Backpropagation

\section{PENDAHULUAN}

Salah satu produk prikanan yang memliki potensi cukup besar untuk dikembangkan di Indonesia adalah rumput laut. Rumput laut memiliki nilai ekonomis yang timggi dan bisa diolah di dalam negeri sehingga dapat meningkatkan nilai tambah bagi petani rumput laut. Budidaya rumput laut di Indonesia terus dikembangkan untuk meningkatkan produksi rumput laut. Disisi lain petani rumput laut diresahkan oleh berbagai gangguan hama dan penyakit yang menyebabkan produksi dan kualitas akan menurun. Salah satu penyakit yang sering menyerang rumput laut adalah penyakit ice-ice [2].

Gejala awal yang diperlihatkan thallus yang terpapar ponyakit ice-ice di Maluku Tengaara yaitu portumbuhan yang lambat, terjadinya perubahan wama merjadi pucat dan pada beberapa cabang thallus menjadi putlh dan membusuk [5]. Kerusakan tanaman akibat ice-ice dapat mencapai $90 \%$ sampai $100 \%$ bila kondisi serangan berlangsung lama. Kondisi ini akan diperparah karena adanya serangan sekunder dari Peryhphyton yang merupakan mikroorganisme akuatik yang umumnya berukuran planktonik, fitoplankton, maupun zooplankton. Serangan sekunder sebagai lanjutan dari kondisi serangan ice-ice dapat pula dilakukan oleh bakteri pathogen seperti Pseudomonas dan Staphylococus [1].

Rumput laut yang terinfeksi penyakit ice-ice akan mengalami perubahan warna. Untuk mengidentifikasi pesubahan warna pada rumput laut yang terinfeksi penyakit dapat menggunakan metode JST BP [6].

Berdasarkan ptermasalahan tersebut, maka peneliti mengusulkan untuk membuat suatu sistem komputasi pengidentifikasian penyakit ice-ice dengan metode jaringan saraf tiruan backpropagation.

\section{LANDASAN TEORI}

Rumput laut (Seaweed) adalah tumbuhan yang daun, batang dan akar terlihat sama, bagian - bagian tersebut disebut (Thallus). Rumput laut jenis Eucheuma Cottoni ini menghasilkan karaginan (karaginofit) sehingga banyak digunakan sebagai salah satu bahan kebutuhan industri yang telah diperdagangkan dipasar internasional. Di Tarakan banyak yang membudidayakan rumput laut yaitu di Kelurahan Pantai Amal yaitu sepanjang garis 
pantai mulai dari Pantai Amal Lama, Pantai Amal Baru hingga Pantai Binalatung terdapat 472 orang petani rumput laut [3].

Penyakit dengan infeksi yang cukup tinggi di negara Asia penghasil Eucheuma adalah penyakit ice-ice [7]. Penyakit ice - ice menyebabkan rumput laut mengalami gangguan fisiologis dan morfologis sehingga memberikan efek bertambah tuanya rumput laut [4]. Dikatakan bahwa gejala-gejala penyakit ice-ice pada rumput laut jenis Eucheuma sp adalah timbulnya bintik atau bercak-bercak merah pada sebagian thallus yang lama kelamaan menjadi kuning pucat dan akhirnya berangsur-angsur menjadi putih dan akhirnya menjadi hancur atau rontok [5].

Citra atau gambar merupakan informasi secara visual sebagai objek dua dimensi yang dihasilkan dari citra analog yang kontinu yang dapat diubah menjadi citra digital diskrit melalui proses sampling. Sampling adalah pemilihan titik-titik untuk mewakili citra digital yang diberikan dimana, sampling sebagai pengurangan signal kontinu menjadi signal diskrit. Citra digital merupakan fungsi dua dimensi $\mathrm{f}(\mathrm{x}, \mathrm{y})$ untuk $\mathrm{f}$ pada titik ( $\mathrm{x}, \mathrm{y})$ merupakan tingkat kecerahan (brightness) sebuah citra pada suatu titik dan $\mathrm{x}$ dan y adalah koordinat spasial.

Pengolahan citra yang dilakukan pada penelitian ini sebagai berikut :

a. Cropping adalah proses pemotongan citra dalam satu bagian untuk mendapatkan citra yang diinginkan [10]. Operasi cropping citra dengan menentukan lebar citra (W) dan tinggi citra $(\mathrm{H})$ dengan rumus:

$\mathrm{W}=\mathrm{x}_{2}-\mathrm{x}_{1}$ dan $\mathrm{H}=\mathrm{y}_{2}-\mathrm{y}_{1}$

b. Gray scale adalah proses pengubahan citra warna menjadi skal keabuan. Proses mengubah citra warna menjadi skala keabuan Pengubahan warna citra menjadi skala keabuan menggunakan rumus:

$\mathrm{Y}=0.299 \mathrm{R}+0.587 \mathrm{G}+0.114 \mathrm{~B}$

Y merupakan nilai skala keabuan dari citra.

c. Threshold merupakan proses pengubahan citra skala keabuan menjadi citra biner. Piksel-piksel yang nilai intensitasnya di bawah 128 akan diubah menjadi hitam (nilai intensitasnya $=0$ ), sedangkan piksel-piksel yang nilai intensitasnya di atas 128 iubah menjadi putih (nilai intensitasnya $256=1$ ).

d. Histogram merupakan probabilitas statistik distribusi pada setiap tingkat abu-abu dalam citra digital [9]. Pada citra skala keabuan 8 bit, intensitasnya ada 256 level nilai yang berbeda. Sehingga histogram akan menampilkan grafik secara terdistribusi dari 256 level nilai piksel.

Jaringan syaraf tiruan (JST) adalah suatu metode komputasi yang meniru sistem jaringan syaraf biologis, untuk JST dapat ditentukan oleh 3 hal yaitu arsitektur jaringan, algoritma, dan fungsi aktivasi dimana pada arsitektur JST backpropagation terdiri dari lapis masukan, lapisan tersembunyi, dan lapis keluaran.

JST dibentuk untuk generalisasi model matematika dari jaringan syaraf biologi dan memiliki berbagai macam metode yang dapat digunakan untuk peramalan atau prediksi. Metode backpropagation adalah metode yang sering digunakan untuk melakukan prediksi. Werbos adalah yang pertama kali merumuskan algoritma pelatihan backpropagation dan dipopulerkan oleh Rumelhart bersama Mc Clelland untuk dipakai pada JST
[8]. Algoritma ini sering disingkat dengan BP. Pelatihan BP menggunakan metode belajar supervisi sehingga mampu mengenali pola masukan suatu data dengan tingkat akurasi yang tinggi dan didesain untuk operasi pada JST feed forward lapis jamak (multi-layer).

\section{METODE PENELITIAN}

Tahapan yang dilakukan dalam merancang system identifikasi penyakit ice-ice pada rumput laut dimulai dari pengambilan data dilanjutkan dengan perancangan system.

Pengambilan sampel data untuk penelitian ini bersifat primer yang akan diambil sebanyak 27 citra rumput laut sehat dan 33 citra rumput laut sakit dimana sampel ini diambil menggunakan kamera HP di Pantai Lama Kota Tarakan pada saat pembudidaya rumput laut baru panen. Metode pengambilan data menggunakan kamera genggam juga dilakukan oleh [9] dalam peneltiannya analisis perbandingan pengolahan citra asli dan hasil croping untuk identifikasi telur.

Metode pengambilan sampel pada setiap rumput laut diambil sekali dan terkadang dua kali atau lebih ketika terlihat pencahayaan kurang baik atau saat citra tidak jelas dengan jarak dan posisi yang sama. Untuk pengambilan sampel data di bedakan menjadi dua yaitu data pelatihan dan pengujian dimana data pelatihan terdiri dari 24 citra yang diperoleh kandidat 6 citra terbaik sebagai data pelatihan yang digunakan yaitu 3 citra rumput laut sehat dan 3 citra rumput laut sakit sedangkan untuk pengujian sebanyak 24 rumput laut sehat dan 30 citra rumput laut sakit.

Dalam perancangan system terdiri dari dua tahapan, yaitu perancangan pengolahan citra dan jaringan syaraf tiruan backagation seperti ditunjukkan dalam gambar 1 . Tahapan proses identifikasi penyakit ice-ice terdiri dari tiga tahapan, yaitu:

\section{A. Proses pengolahan citra}

Proses pengolahan citra rumput laut terdiri dari cropping, gray scale, threshold dan histogram. Tujuan citra dilakukan cropping adalah untuk memotong bagian citra yang diinginkan dengan cara cropping manual berdasarkan nilai panjang dan lebar yang sama pada setiap citra yaitu $40 \times 35$ piksel dan menentukan nilai $\mathrm{x}$ dan $\mathrm{y}$ untuk memindahkan posisi cropping, nilai $\mathrm{x}$ dan y dapat berubah-ubah sesuai posisi yang diinginkan. Gray scale bertujuan untuk mengubah Citra RGB (Red, Green Blue) menjadi citra skala keabuan 0-255. Untuk threshold berfungsi untuk mengetahui dan membedakan citra rumput laut sakit dan sehat secara manual dengan menggeserkan skala keabuan 0-255 sehingga menghasilkan nilai biner dimana 0 menunjukan citra sakit dan 1 menunjukan citra sehat. Hasil dari gray scale dan threshold berupa histogram dan data yang akan tersimpan ke data base terdiri dari dua format file yaitu bitmap (bmp) dan text document (txt). 

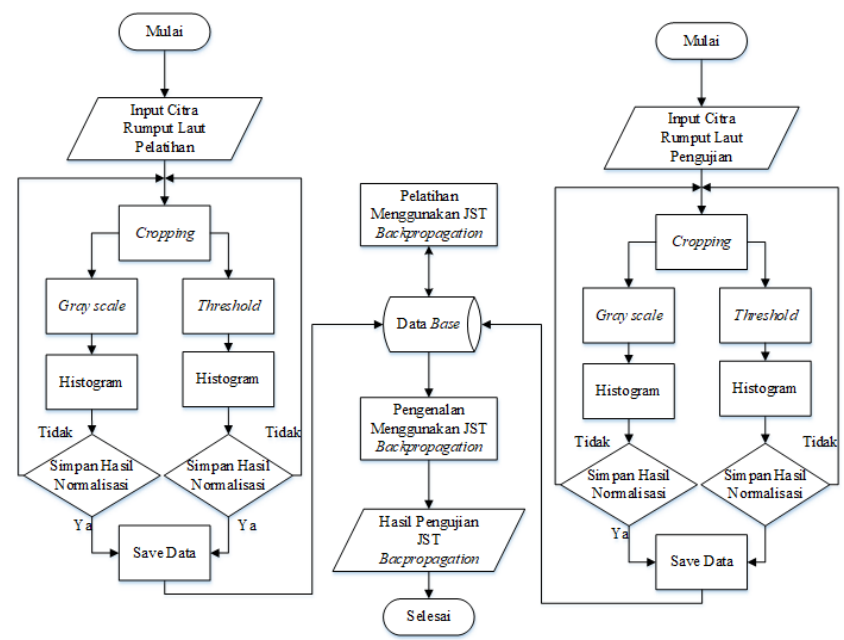

Gambar 1. Perancangan system identifikasi penyakit ice-ice

\section{B. Proses pelatihan}

Proses pelatihan ini dimulai dengan tugas pemberian nilai bobot awal kemudian proses maju, menghitung nilai error. Apabila nilai error lebih kecil daripada batasan error maka bobot akhir akan disimpan, namun ketika error tidak lebih kecil dari batasan error maka akan dilakukan proses mundur untuk menghasilkan bobot baru. Dimana arsitektur jaringan yang digunakan pada JST BP pada penelitian ini dapat dilihat dalam Gambar .2. Arsitektur jaringan pada Gambar 2 terdiri dari 3 lapisan yaitu lapisan masuk, lapisan tersembunyi dan lapisan keluaran. Pada lapisan masukan terdiri dari 256 neuron yang didapatkan dari proses histogram citra gray scale (0-255), jumlah neuron lapisan tersembunyi adalah 2, dimana tiap lapisan di berikan dengan variasi agar mendapatkan error terbaik.

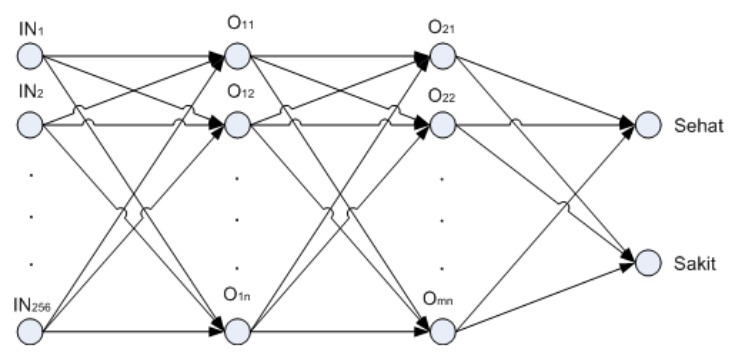

Gambar 1 Arsitektur jaringan proses pelatihan JST backpropagation

Untuk lapisan keluaran terdiri dari 2 neuron dimana hasilnya menunjukan sehat dan sakit yang diwakili onel nilai biner (0 dan 1).

Proses JST backpropagation dapat dijelaskan lebih rinci yaitu sebagai berikut :

a. Masukan JST yang diberikan berupa nilai piksel yang dipresentrasikan ke angka biner 0 dan 1 dengan jumlah 256 skala keabuan.

b. Kemudian masukan tersebut akan diteruskan ke lapis tersembunyi 1.

c. Ketika telah mendapatkan keluaran pada lapisan tersembunyi 1 sebanyak 5 unit, ke- 5 unit akan dilakukan aktivasi dan diteruskan ke lapisan tersembunyi 2. Dimana jumlah unit lapisan tersembunyi 1 sama dengan jumlah lapisan tersembunyi 5 dengan aktivasi yang sama. Masingmasing keluaran lapisan 1 akan disimpan sementara di temp1j sedangkan keluaran lapisan 2 akan disimpan sementara di temp2j.

d. Keluaran lapisan tersembunyi 2 akan diteruskan ke unit - unit lapisan keluaran. Keluaran terdiri dari 2 unit yang selanjutnya akan dibandingkan dengan target yang diinginkan. Untuk target yang diinginkan yaitu $\mathrm{t} 1=0$ untuk rumput laut sehat dan $\mathrm{t} 2=1$ untuk rumput laut sakit dengan ketentuan apabila keluaran $\leqslant 0,5$ maka hasilnya 0 sedangkan jika keluaran $\geqslant 0,5$ maka hasilnya 1 . Jika hasil tidak sesuai ketentuan maka dilakukan proses mundur untuk memperbaiki bobot - bobot baru.

e. Terselesaikannya proses pelatihan, maka selanjutnya akan dilakukkan penyimpanan bobot yang telah dihasilkan.

f. Memeriksa kondisi berhenti, kondisi berhenti pada proses pelatihan JST BP pada penelitian ini menggunakan metode Mean Square Error (MSE) untuk membatasi error dengan cara menghitung ratarata dari keluaran.

\section{Proses pengujian menggunakan JST BP}

Pada proses pengujian pertama ambil data uji kemudian Load bobot pelatihan dan hasilnya dibandingkan dengan target sehingga hasil uji akan di tampilkan apakah rumput laut terinfeksi penyakit ice-ice atau tidak.

Untuk mengetahui tingkat keberhasilan dari sistem akan dilakukan perhitungan tingkat akurasi dengan menggunakan persamaan 3 .

Akurasi $\%=\frac{\text { Jumlah Data Sesuai Targt }}{\text { Jumlah Data }} .100$

\section{HASIL DAN PEMBAHASAN}

Hasil yang diperoleh dari rancang bangun system identifikasi penyakait ice-ice pada rumput laut dilakukan mulai dari proses pengolahan citra, pelatihan dan pengujian menggunakan JST BP. Proses pengolahan citra dimulai dengan cropping citra rumput laut dengan format bitmap (.bmp), dengan ukuran cropping 40×35 piksel pada semua sampel data dan posisi cropping dapat diubah dengan menentukan nilai $\mathrm{x}$ dan y secara manual. Hal ini dapat dilihat dalam Gambar 3

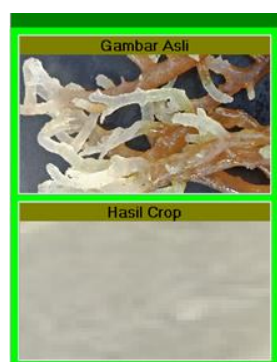

(a)

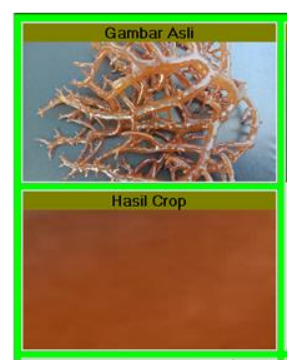

(b)
Gambar 3 (a) Tampilan hasil cropping citra rumput laut sakit (b) Tampilan hasil cropping citra rumput laut sehat 
Proses selanjutnya dalam pengolahan citra adalah proses gray scale dan histogram citra untuk mendapatkan nilai piksel citra rumput laut sakit dan sehat, seperti ditunjukkan dalam Gambar 4.

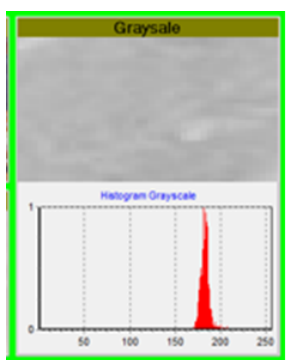

(a)

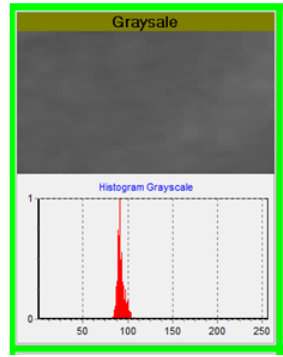

(b)
Gambar 4. (a) Tampilan hasil citra gray scale dan histogram citra rumput laut sakit (b) Tampilan hasil citra gray scale dan histogram citra rumput laut sehat

Dalam Gambar 4(a) nilai histogram citra rumput laut sakit berada pada rentang 170-200 piksel dan nilai histogram untuk citra rumput laut sehat berada pada rentang 82-103 piksel. Proses terakhir dalam pengolahan citra adalah melakukan proses threshold untuk menghasilkan histogram dengan nilai biner tujuannya agar dapat mengetahui perbedaan citra rumput laut yang sakit dan sehat dimana perbedaan tampilan threshold dan histogramnya dapat terlihat dari warna putih diwakili dengan angka 1 dan untuk bagian citra rumput laut sakit dan bagian citra berwarna hitam diwakili dengan angka 2 merupakan bagian citra sehat. Tampilan tersebut dapat dilihat dalam Gambar 5.

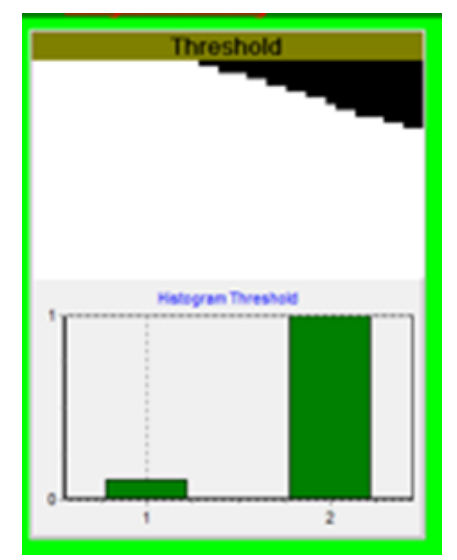

\section{Gambar 5 Hasil tampilan threshold pada citra rumput laut}

Data rumput laut dari hasil pemrosesan citra dapat dilihat dalam tabel I.
Tabel I

Data Hasil pengolahan citra

\begin{tabular}{|c|c|c|c|c|c|c|c|}
\hline \multirow{2}{*}{ No. } & \multirow{2}{*}{$\begin{array}{c}\text { Nama } \\
\text { Citra }\end{array}$} & \multirow{2}{*}{$\begin{array}{c}\text { Kodisi } \\
\text { Citra }\end{array}$} & \multirow{2}{*}{ Panjang } & \multirow{2}{*}{ Lebar } & \multicolumn{2}{|c|}{ Posisi } & \multirow{2}{*}{$\begin{array}{l}\text { Nilai } \\
\text { Piksel }\end{array}$} \\
\hline & & & & & $\mathrm{x}$ & $\mathrm{Y}$ & \\
\hline 1 & Sakit1 & Sakit & 40 & 35 & 942 & 522 & $168-210$ \\
\hline 2 & Sakit2 & Sakit & 40 & 35 & 740 & 605 & $224-243$ \\
\hline 3 & Sakit3 & Sakit & 40 & 35 & 2190 & 614 & $184-206$ \\
\hline 4 & Sehat1 & Sehat & 40 & 35 & 1825 & 907 & $82-109$ \\
\hline 5 & Sehat2 & Sehat & 40 & 35 & 1825 & 1001 & $72-103$ \\
\hline 6 & Sehat3 & Sehat & 40 & 35 & 2068 & 1232 & $102-136$ \\
\hline 7 & Sal & Sakit & 40 & 35 & 2508 & 964 & $157-204$ \\
\hline 8 & $\mathrm{Sa} 2$ & Sakit & 40 & 35 & 2117 & 1746 & $176-203$ \\
\hline 9 & $\mathrm{Sa} 3$ & Sakit & 40 & 35 & 1467 & 823 & $155-200$ \\
\hline 10 & Sa4 & Sakit & 40 & 35 & 1008 & 926 & $181-215$ \\
\hline 11 & $\mathrm{Sa} 5$ & Sakit & 40 & 35 & 343 & 277 & $168-221$ \\
\hline 12 & $\mathrm{Sa6}$ & Sakit & 40 & 35 & 1598 & 882 & $180-212$ \\
\hline 13 & Sa7 & Sakit & 40 & 35 & 2512 & 770 & $168-232$ \\
\hline 14 & $\mathrm{Sa} 8$ & Sakit & 40 & 35 & 2025 & 698 & $162-209$ \\
\hline 15 & Sa9 & Sakit & 40 & 35 & 2115 & 364 & $153-173$ \\
\hline 16 & Sa10 & Sakit & 40 & 35 & 1000 & 728 & $174-208$ \\
\hline 17 & Sal1 & Sakit & 40 & 35 & 2070 & 736 & $179-207$ \\
\hline 18 & Sa12 & Sakit & 40 & 35 & 1894 & 355 & $174-212$ \\
\hline 19 & Sa13 & Sakit & 40 & 35 & 2656 & 900 & $166-210$ \\
\hline 20 & Sa14 & Sakit & 40 & 35 & 3863 & 1709 & $168-208$ \\
\hline 38 & $\mathrm{Se} 2$ & Sehat & 40 & 35 & 1436 & 515 & $110-139$ \\
\hline 39 & $\mathrm{Se} 3$ & Sehat & 40 & 35 & 1922 & 685 & $65-109$ \\
\hline 40 & $\mathrm{Se} 4$ & Sehat & 40 & 35 & 2003 & 983 & $109-138$ \\
\hline 41 & Se5 & Sehat & 40 & 35 & 1867 & 1078 & $126-145$ \\
\hline 42 & Se6 & Sehat & 40 & 35 & 2006 & 805 & $76-120$ \\
\hline 43 & $\mathrm{Se} 7$ & Sehat & 40 & 35 & 2753 & 760 & $113-148$ \\
\hline 44 & $\mathrm{Se} 8$ & Sehat & 40 & 35 & 2753 & 799 & $115-149$ \\
\hline 45 & $\mathrm{Se} 9$ & Sehat & 40 & 35 & 2771 & 786 & $130-144$ \\
\hline 46 & Se10 & Sehat & 40 & 35 & 2672 & 788 & $114-143$ \\
\hline 47 & Se11 & Sehat & 40 & 35 & 2673 & 746 & 76-132 \\
\hline 48 & Se12 & Sehat & 40 & 35 & 2795 & 688 & $104-140$ \\
\hline 49 & Se13 & Sehat & 40 & 35 & 1582 & 744 & $127-145$ \\
\hline 50 & Se14 & Sehat & 40 & 35 & 3122 & 1160 & 104-144 \\
\hline 51 & Se15 & Sehat & 40 & 35 & 1955 & 403 & $128-147$ \\
\hline 52 & Se16 & Sehat & 40 & 35 & 1989 & 434 & $110-126$ \\
\hline 53 & Se17 & Sehat & 40 & 35 & 2531 & 886 & $113-143$ \\
\hline 54 & Se18 & Sehat & 40 & 35 & 1982 & 819 & $92-142$ \\
\hline 55 & Se19 & Sehat & 40 & 35 & 1850 & 890 & 79-149 \\
\hline 56 & $\mathrm{Se} 20$ & Sehat & 40 & 35 & 2384 & 1101 & 104-145 \\
\hline 57 & $\mathrm{Se} 21$ & Sehat & 40 & 35 & 2558 & 992 & $87-127$ \\
\hline 58 & $\mathrm{Se} 22$ & Sehat & 40 & 35 & 2640 & 1051 & $78-93$ \\
\hline 59 & $\mathrm{Se} 23$ & Sehat & 40 & 35 & 2576 & 1060 & 74-135 \\
\hline 60 & $\mathrm{Se} 24$ & Sehat & 40 & 35 & 1995 & 791 & 95-144 \\
\hline
\end{tabular}

\begin{tabular}{|c|c|c|c|c|c|c|c|}
\hline \multirow{2}{*}{ No. } & \multirow{2}{*}{$\begin{array}{c}\text { Nama } \\
\text { Citra }\end{array}$} & \multirow{2}{*}{$\begin{array}{c}\text { Kodisi } \\
\text { Citra }\end{array}$} & \multirow{2}{*}{ Panjang } & \multirow{2}{*}{ Lebar } & \multicolumn{2}{|c|}{ Posisi } & \multirow{2}{*}{$\begin{array}{c}\text { Nilai } \\
\text { Piksel }\end{array}$} \\
\hline & & & & & $\mathrm{X}$ & $\mathrm{Y}$ & \\
\hline 1 & Sakit1 & Sakit & 40 & 35 & 942 & 522 & $168-210$ \\
\hline 2 & Sakit2 & Sakit & 40 & 35 & 740 & 605 & $224-243$ \\
\hline 3 & Sakit3 & Sakit & 40 & 35 & 2190 & 614 & $184-206$ \\
\hline 4 & Sehat1 & Sehat & 40 & 35 & 1825 & 907 & $82-109$ \\
\hline 5 & Sehat2 & Sehat & 40 & 35 & 1825 & 1001 & $72-103$ \\
\hline 6 & Sehat3 & Sehat & 40 & 35 & 2068 & 1232 & $102-136$ \\
\hline 7 & Sa1 & Sakit & 40 & 35 & 2508 & 964 & $157-204$ \\
\hline 8 & $\mathrm{Sa} 2$ & Sakit & 40 & 35 & 2117 & 1746 & $176-203$ \\
\hline 9 & $\mathrm{Sa} 3$ & Sakit & 40 & 35 & 1467 & 823 & $155-200$ \\
\hline 10 & Sa4 & Sakit & 40 & 35 & 1008 & 926 & $181-215$ \\
\hline 11 & Sa5 & Sakit & 40 & 35 & 343 & 277 & $168-221$ \\
\hline 12 & Sa6 & Sakit & 40 & 35 & 1598 & 882 & $180-212$ \\
\hline 13 & $\mathrm{Sa} 7$ & Sakit & 40 & 35 & 2512 & 770 & $168-232$ \\
\hline 14 & $\mathrm{SaS}$ & Sakit & 40 & 35 & 2025 & 698 & $162-209$ \\
\hline 15 & Sa9 & Sakit & 40 & 35 & 2115 & 364 & $153-173$ \\
\hline 16 & Sa10 & Sakit & 40 & 35 & 1000 & 728 & $174-208$ \\
\hline 17 & Sa11 & Sakit & 40 & 35 & 2070 & 736 & $179-207$ \\
\hline 18 & Sa12 & Sakit & 40 & 35 & 1894 & 355 & $174-212$ \\
\hline 19 & Sa13 & Sakit & 40 & 35 & 2656 & 900 & $166-210$ \\
\hline 20 & Sa14 & Sakit & 40 & 35 & 3863 & 1709 & $168-208$ \\
\hline 21 & Sa15 & Sakit & 40 & 35 & 2022 & 954 & $165-208$ \\
\hline 22 & Sa16 & Sakit & 40 & 35 & 2096 & 806 & $168-195$ \\
\hline 23 & Sa17 & Sakit & 40 & 35 & 2318 & 837 & $172-222$ \\
\hline 24 & Sa18 & Sakit & 40 & 35 & 979 & 907 & $170-207$ \\
\hline 25 & Sa19 & Sakit & 40 & 35 & 2796 & 993 & $176-201$ \\
\hline 26 & $\mathrm{Sa20}$ & Sakit & 40 & 35 & 3043 & 582 & $162-205$ \\
\hline 27 & Sa21 & Sakit & 40 & 35 & 2043 & 606 & $160-222$ \\
\hline 28 & $\mathrm{Sa} 22$ & Sakit & 40 & 35 & 1206 & 1171 & $181-210$ \\
\hline 29 & Sa23 & Sakit & 40 & 35 & 3482 & 682 & $177-221$ \\
\hline 30 & $\mathrm{Sa} 24$ & Sakit & 40 & 35 & 1078 & 1080 & $155-174$ \\
\hline 31 & Sa25 & Sakit & 40 & 35 & 1063 & 1028 & $180-217$ \\
\hline 32 & Sa26 & Sakit & 40 & 35 & 1828 & 970 & $172-197$ \\
\hline 33 & $\mathrm{Sa} 27$ & Sakit & 40 & 35 & 1757 & 950 & $168-206$ \\
\hline 34 & Sa28 & Sakit & 40 & 35 & 1745 & 888 & $175-218$ \\
\hline 35 & Sa29 & Sakit & 40 & 35 & 881 & 410 & $171-208$ \\
\hline 36 & Sa30 & Sakit & 40 & 35 & 3493 & 787 & $152-189$ \\
\hline 37 & $\mathrm{Se} 1$ & Sehat & 40 & 35 & 1026 & 975 & $114-143$ \\
\hline
\end{tabular}


Hasil pengolahan citra dalam tabel I dapat dianalisa bahwa nilai piksel citra rumput laut sakit berada pada posisi nilai piksel terkecil adalah 152, sedangkan yang terbesar adalah 243. Untuk citra rumput laut sehat berada pada nilai terkecil 65 dan yang terbesar adalah 149. Hal ini berarti bahwa untuk citra rumput laut sakit nilai piksel berkisar 152-243 sedangkan nilai piksel untuk citra rumput laut sehat berkisar 65-149.

Pada proses pelatihan yang dilakukan pada sistem perangkat lunak pertama kali adalah menentukan nilai batasan error dimana pada penelitian ini menggunakan $10-3=0,001$, jumlah inputan yaitu 256 , lapisan tersembunyi 1 dan 2 diberikan jumlah neuron bervariasi dengan variasi 5 dan 5, 10 dan 10, 20 dan 20,25 dan 25. Inputan data yang dilatih merupakan data terbaik yang diperoleh dari 24 citra dimana berjumlah 6 ( 3 sakit dan 3 sehat) dengan format document text (.ext) dan memiliki 2 keluaran yaitu sakit dan sehat . Laju pembelajan yang dilakukan sebanyak 4 kali yaitu $0,1-0,4$. Berikut ini merupakan hasil dari pelatihan menggunakan JST BP dalam Tabel II.

Tabel II

Hasil Pelatihan Menggunakan JST BP

\begin{tabular}{|c|c|c|c|c|}
\hline $\begin{array}{c}\text { Laju } \\
\text { Pembelajara }\end{array}$ & Jumlah Masukan & $\begin{array}{l}\text { Jumlah } \\
\text { Neuron }\end{array}$ & Iterasi & Error \\
\hline \multirow{4}{*}{0,1} & 6 & 5 dan 5 & 487731 & 0,009999 \\
\hline & 6 & 10 dan 10 & 330245 & 0,009999 \\
\hline & 6 & 20 dan 20 & 127203 & 0,009999 \\
\hline & 6 & 25 dan 25 & 114008 & 0,009999 \\
\hline \multirow{4}{*}{0,2} & 6 & 5 dan 5 & 744638 & 0,009999 \\
\hline & 6 & 10 dan 10 & 219771 & 0,009999 \\
\hline & 6 & 20 dan 20 & 150765 & 0,009997 \\
\hline & 6 & 25 dan 25 & 108807 & 0,009999 \\
\hline \multirow[t]{4}{*}{0,3} & 6 & 5 dan 5 & 890665 & 0,009998 \\
\hline & 6 & 10 dan 10 & 364692 & 0,009997 \\
\hline & 6 & 20 dan 20 & 693671 & 0,009998 \\
\hline & 6 & 25 dan 25 & 880970 & 0,009997 \\
\hline \multirow[t]{4}{*}{0,4} & 6 & 5 dan 5 & 1362612 & 0,009999 \\
\hline & 6 & 10 dan 10 & 1022048 & 0,009995 \\
\hline & 6 & 20 dan 20 & 3240390 & 0,009994 \\
\hline & 6 & 25 dan 25 & 3035948 & 0,009991 \\
\hline
\end{tabular}

Dalam Tabel II terlihat bahwa nilai error terbaik berada pada laju pembelajaran 0,2 dengan jumlah neuron 25 dan 25 yaitu 0,009999 dengan iterasi 108807. Hal tersebut dikarenakan nilai error terbaik memiliki kriteria iterasi cepat dan nilai error kecil mendekati nilai target error $(0,001)$.

Proses pengujian sistem perangkat lunak menggunakan JST BP citra yang di uji sebanyak 60 citra yaitu 6 data citra hasil pelatihan dan 54 data citra rumput laut yang terdiri dari 30 citra rumput laut sakit dan 24 citra rumput laut sehat. Hasil pengujian dapat dilihat dalam Tabel 3.
Tabel III

Hasil Pengujian

\begin{tabular}{|c|c|c|c|c|}
\hline No & $\begin{array}{c}\text { Nama } \\
\text { Citra }\end{array}$ & Target & Hasil Uji & Keterangan \\
\hline 1 & Sakit1 & Terinfeksi & Terinfeksi & Benar \\
\hline 2 & Sakit2 & Terinfeksi & Terinfeksi & Benar \\
\hline 3 & Sakit3 & Terinfeksi & Terinfeksi & Benar \\
\hline 4 & Sehat1 & Tidak Terinfeksi & Tidak Terinfeksi & Benar \\
\hline 5 & Sehat2 & Tidak Terinfeksi & Tidak Terinfeksi & Benar \\
\hline 6 & Sehat3 & Tidak Terinfeksi & Tidak Terinfeksi & Benar \\
\hline 7 & Sal & Terinfeksi & Terinfeksi & Benar \\
\hline 8 & $\mathrm{Sa} 2$ & Terinfeksi & Terinfeksi & Benar \\
\hline 9 & $\mathrm{Sa} 3$ & Terinfeksi & Terinfeksi & Benar \\
\hline 10 & $\mathrm{Sa} 4$ & Terinfeksi & Terinfeksi & Benar \\
\hline 11 & $\mathrm{Sa} 5$ & Terinfeksi & Terinfeksi & Benar \\
\hline 12 & Sa6 & Terinfeksi & Terinfeksi & Salah \\
\hline 13 & $\mathrm{Sa} 7$ & Terinfeksi & Terinfeksi & Benar \\
\hline 14 & $\mathrm{Sa} 8$ & Terinfeksi & Terinfeksi & Benar \\
\hline 15 & $\mathrm{Sa9}$ & Terinfeksi & Tidak Terinfeksi & Salah \\
\hline 16 & Sa10 & Terinfeksi & Terinfeksi & Benar \\
\hline 17 & Sa11 & Terinfeksi & Terinfeksi & Benar \\
\hline 18 & Sa12 & Terinfeksi & Terinfeksi & Benar \\
\hline 19 & Sa13 & Terinfeksi & Terinfeksi & Benar \\
\hline 20 & Sal4 & Terinfeksi & Terinfeksi & Benar \\
\hline 21 & Sa15 & Terinfeksi & Terinfeksi & Benar \\
\hline 22 & Sa16 & Terinfeksi & Terinfeksi & Benar \\
\hline 23 & Sa17 & Terinfeksi & Terinfeksi & Benar \\
\hline 24 & Sa18 & Terinfeksi & Terinfeksi & Benar \\
\hline 25 & Sa19 & Terinfeksi & Terinfeksi & Benar \\
\hline 26 & $\mathrm{Sa} 20$ & Terinfeksi & Terinfeksi & Benar \\
\hline 27 & $\mathrm{Sa} 21$ & Terinfeksi & Terinfeksi & Benar \\
\hline 28 & $\mathrm{Sa} 22$ & Terinfeksi & Terinfeksi & Benar \\
\hline 29 & $\mathrm{Sa} 23$ & Terinfeksi & Terinfeksi & Benar \\
\hline 30 & $\mathrm{Sa} 24$ & Terinfeksi & Tidak Terinfeksi & Salah \\
\hline 31 & $\mathrm{Sa} 25$ & Terinfeksi & Terinfeksi & Benar \\
\hline 32 & $\mathrm{Sa} 26$ & Terinfeksi & Terinfeksi & Benar \\
\hline 33 & $\mathrm{Sa} 27$ & Terinfeksi & Terinfeksi & Benar \\
\hline 34 & $\mathrm{Sa} 28$ & Terinfeksi & Terinfeksi & Benar \\
\hline 35 & $\mathrm{Sa} 29$ & Terinfeksi & Terinfeksi & Benar \\
\hline 36 & $\mathrm{Sa} 30$ & Terinfeksi & Tidak Terinfeksi & Salah \\
\hline 37 & $\mathrm{Se} 1$ & Tidak Terinfeksi & Tidak Terinfeksi & Benar \\
\hline 38 & $\mathrm{Se} 2$ & Tidak Terinfeksi & Tidak Terinfeksi & Benar \\
\hline 39 & $\mathrm{Se} 3$ & Tidak Terinfeksi & Tidak Terinfeksi & Benar \\
\hline 40 & $\mathrm{Se} 4$ & Tidak Terinfeksi & Tidak Terinfeksi & Benar \\
\hline 41 & $\mathrm{Se} 5$ & Tidak Terinfeksi & Tidak Terinfeksi & Benar \\
\hline 42 & $\mathrm{Se} 6$ & Tidak Terinfeksi & Tidak Terinfeksi & Benar \\
\hline 43 & $\mathrm{Se} 7$ & Tidak Terinfeksi & Tidak Terinfeksi & Benar \\
\hline 44 & $\mathrm{Se} 8$ & Tidak Terinfeksi & Tidak Terinfeksi & Benar \\
\hline 45 & $\mathrm{Se} 9$ & Tidak Terinfeksi & Tidak Terinfeksi & Benar \\
\hline 46 & Se10 & Tidak Terinfeksi & Tidak Terinfeksi & Benar \\
\hline 47 & Sel1 & Tidak Terinfeksi & Tidak Terinfeksi & Benar \\
\hline 48 & $\mathrm{Se} 12$ & Tidak Terinfeksi & Tidak Terinfeksi & Benar \\
\hline 49 & $\mathrm{Se} 13$ & Tidak Terinfeksi & Tidak Terinfeksi & Benar \\
\hline 50 & $\mathrm{Se} 14$ & Tidak Terinfeksi & Tidak Terinfeksi & Benar \\
\hline 51 & Se15 & Tidak Terinfeksi & Tidak Terinfeksi & Benar \\
\hline 52 & Se16 & Tidak Terinfeksi & Tidak Terinfeksi & Benar \\
\hline 53 & $\mathrm{Se} 17$ & Tidak Terinfeksi & Tidak Terinfeksi & Benar \\
\hline 54 & $\mathrm{Se} 18$ & Tidak Terinfeksi & Tidak Terinfeksi & Benar \\
\hline 55 & $\mathrm{Se} 19$ & Tidak Terinfeksi & Tidak Terinfeksi & Benar \\
\hline 56 & $\mathrm{Se} 20$ & Tidak Terinfeksi & Tidak Terinfeksi & Benar \\
\hline 57 & $\mathrm{Se} 21$ & Tidak Terinfeksi & Tidak Terinfeksi & Benar \\
\hline 58 & $\mathrm{Se} 22$ & Tidak Terinfeksi & Tidak Terinfeksi & Benar \\
\hline 59 & $\mathrm{Se} 23$ & Tidak Terinfeksi & Tidak Terinfeksi & Benar \\
\hline 60 & $\mathrm{Se} 24$ & Tidak Terinfeksi & Tidak Terinfeksi & Benar \\
\hline
\end{tabular}

Untuk perhitungan tingkat keberhasilan sistem perangkat lunak dapat diketahui dengan menggunakan persamaan 1 , yaitu:

$$
\text { Akurasi } \%=\frac{\text { Jumlah Data Sesuai Targt }}{\text { Jumlah Data }} \times 100
$$


1. Data citra hasil pelatihan:

$$
\text { Akurasi } \%=\frac{6}{6} \times 100=100 \%
$$

2. Data citra hasil pengujian

a. Citra rumput laut sakit :

b. Citra rumput laut sehat:

$$
\text { Akurasi } \%=\frac{27}{30} \times 100=90 \%
$$

$$
\text { Akurasi } \%=\frac{24}{24} \times 100=100 \%
$$

3. Citra rumput laut keseluruhan :

$$
\text { Akurasi } \%=\frac{57}{60} \times 100=95 \%
$$

4. Nilai akurasi kegagalan :

$$
\text { Akurasi } \%=\frac{3}{60} \times 100=5 \%
$$

Berdasarkan hasil data dan perhitungan tingkat keberhasilan maka dapat dianalisa bahwa terdapat kesalahan pada data citra rumput laut sakit yaitu sebanyak 3 data sehingga tingkat keberhasilan citra hasil pelatihan sebesar $100 \%$ citra rumput laut sakit sebesar $90 \%$, citra rumput laut sehat sebesar $100 \%$, citra rumput laut keseluruhan sebesar 95\% dan nilai akurasi kegagalan sebesar 5\%. Terjadinya kesalahan pada data citra rumput laut sakit ini dapat terjadi karena nilai piksel pada citra rumput laut sakit tersebut mendekati nilai citra rumput laut sehat. Nilai piksel hasil pengujian data yang salah yaitu pada Sa9 (153-173), Sa24 (155-174) dan Sa30 (152 -189) dimana nilai piksel data tersebut mendekati kisaran nilai piksel sehat yaitu 65-149. Faktor lain yang mempengaruhi kesalahan pengujian data tersebut adalah penentuan posisi cropping pada saat pengolahan citra dan kualitas citra itu sendiri yang terdapat bayangan atau pencahayaan yang kurang baik. Peneliti menggunakan metode JST Backpropagation dikarenakan metode ini dapat mengatasi hasil dari pengolahan citra yang terkadang menghasilkan nilai piksel yang tidak sesuai dengan kisaran sakit atau sehat sehingga tujuan dari penggunaan metode ini agar sistem dapat mengenali penyakit ice-ice yang berada diluar batas kisaran yang dihasilkan dan menetukan apakah citra rumput laut tersebut terinfeksi penyakit ice-ice atau tidak.

\section{KESIMPULAN}

Dari hasil rancang bangun sistem identifikasi menggunakan JST BP yang telah dilakukan pengujian terhadap data citra rumput laut sehat dan citra rumput laut yang terinfeksi penyakit ice-ice sebanyak 60 data maka menghasilkan tingkat akurasi $95 \%$. Ketidak akuratan sistem 5\% dipoengaruhi oleh data citra yang kurang baik dalam pengambilan citra menggunkan kamera HP.

\section{UCAPAN TERIMA KASIH}

Terimakasih atas kesempatan dan fasilitas yang diberikan Program Studi Teknik Elektro, Fakultas Teknik dan Universitas Borneo Tarakan dan semua pihak yang membantu saat penelitian sehingga penulis dapat menyelesaikan penelitian ini.

\section{REFERENSI}

[1] Anggadiredja, J. T., Ahmad Zatnika, Heri Purwanto Dan Sri Istini. "Rumput Laut". Penerbit Swadaya. Jakarta. 2006.

[2] Aris, M. Identifikasi, "Patogenisitas Bakteri dan Pemanfaatan Gen 16s-Rrna Untuk Deteksi Penyakit Ice ice Pada budidaya Rumput Laut (Kappaphycus Alvarezii)". Scientific Repository. (Thesis). Sekolah PascaSarjana Institut Pertanian Bogor (IPB). Bogor. 2011.

[3] Badan Pusat Statistik Kota Tarakan 2016

[4] Doty,M.. "Status of Marine Agronomy", With Special Reference to the Tropics. Proc.of the IXth International Seaweed Symposium. 35-58. 1979.

[5] Fitrian,T. "Hama Penyakit (Ice-ice) Pada Budidaya Rumput Laut Studi Kasus Maluku Tenggara". Oseana. XL(4): 1-10. 2015.

[6] Harto,D.,dkk. "Aplikasi Jaringan Syaraf Tiruan Untuk Mendeteksi White Spot". Jurnal EECCIS. 6(1): 75-82. 2012.

[7] Phillips,M. "Environmental aspects of seaweed cultured". Technical Resources Papers Regional Workshop On The Culture and Utilization Seaweed Volume II. Network of Aquaculture Centre in Asia. Thailand. 51-59 p. 1990.

[8] Purnomo, M. H dan Agus Kurniawan. "Supervised Neural Networks dan Aplikasinya". Yogyakarta: Graha IImu. 2006.

[9] Saifullah,S, Sunardi, Yudhana, A. (2016). "Analisis Perbandingan Pengolahan Citra Asli Dan Hasil Croping Untuk Identifikasi Telur". Jurnal Teknik Informatika dan Sistem Informasi Volume 2 Nomor 3. 2016.

[10] Sutoyo,T. "Teori Pengolahan Citra Digital'. Yogyakarta dan Semarang: ANDI dan UDINUS. 2009. 